\title{
Laulupeod rahvusliku identiteedi kandjana
}

\section{$\underline{\text { Kristin Kuutma }}$}

Laulmine kui kunstiline väljendusvahend peegeldab ühiskonna sotsiaal-kultuurilises kontekstis toimuvaid muutusi, lauluharrastus võib märkimisväärse mehhanismina mõjutada sotsiaalset käitumist, osutuda rahvusliku vabaduspüüdluse kultuuriliseks väljendusvahendiks. Traditsioonilises ühiskonnas oli laulmine kogukonna sisese suhtlemise süsteemi üks osa, ning selle esmane funktsionaalne tähendus oli seotud traditsiooniliste riitustega, kombetalitustega. Laulmine ei omanud konkreetset esteetilist eesmärki, puudus kirjalik tekst, laul oli vahendiks tunnete interpreteerimisel, sõnumite edastamisel, ühtlasi tugevdati rühmaidentiteeti. Eesti vanem laulutraditsioon, regivärsiline rahvalaul on oma esituslaadilt hulgakesi laulmist soosiv (eeslaulja poolt lauldud värssi korratakse koos). Meie esivanemate muusikalise mõtlemise muutusele ja samal

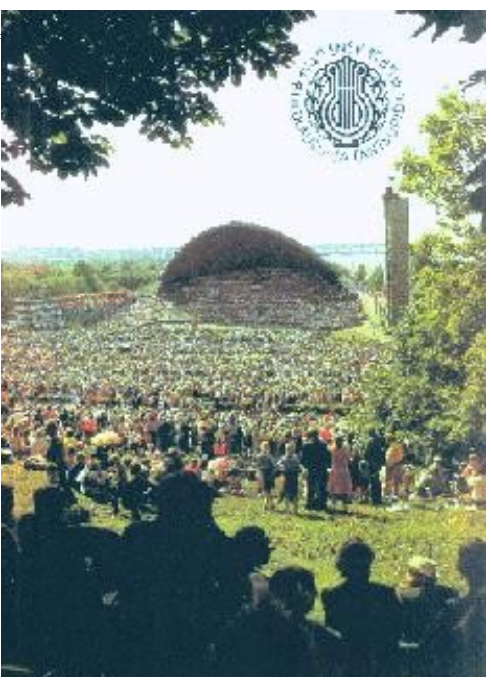
ajal ka enesehinnangu tõusule andis tugeva tõuke talurahva seas levinud vennastekoguduse liikumine, mis tekkis 18. sajandil Eestisse jõudnud hernhuutlaste tegevuse tulemusena. Usulise vagaduse propageerimise kõrval oli vennastekogudus pärisorisele talupojale võrdõiguslikkuse ideed arendav inimkooslus, kus ei tunnistatud seisuste vahesid. Vennastekoguduse tegevuses oli olulisel kohal ühislaulmine, lauldi vaimulikke laule, mis vendade poolt eelkõige Saksamaal kirjutatud, ja kirikulaule, mis tõi kaasa selle hoopis teistsuguse laulutraditsiooni folkloriseerumise. Ametlik luterlik kirik ja külakoolid õpetasid omakorda põhiliselt saksa eeskuju järgivat mitmehäälset koorilaulu. Juba 17. sajandi lõpuks oli ilmunud vähemalt viis eestikeelset koraaliraamatut, mida kasutati köstrikoolides (Leichter 1991, 11-12).

Esimene teade neljahäälsest kooris laulmisest eestlaste hulgas pärineb aastast 1818, mil vastav üleskirjutus tehti Kanepi kihelkonnakooli kohta (asutatud 1804). 1822. aastal asutati Laiusel omaaegselt väga edumeelne kihelkonnakool, kuhu võeti ka tütarlapsi, selles koolis peeti laulutunde iga päev ja 1828. aastast pärineb teade seal tegutsenud suuremast meeskoorist (Leichter 1991, 36). Koorilaulu laiemale levikule talurahva seas pandi alus koolis ja kirikus, 19. sajandi 30-ndatel aastatel algas mitmehäälse koorilaulu areng. Koorilaulu kui seltsitegevuse eeskuju võeti baltisakslastelt, kelle hulgas levis otseselt saksa kultuuri mõjutustel tekkinud mitmehäälset meestelaulu või ka segakoorilaulu kultiveeriv lauluseltside-liikumine. Saksamaal oli see sakslaste ühinemissoovi kajastava rahvusluse üheks avaldumisviisiks. Need seltsid ei olnud üksnes laulukoorid, vaid täitsid ka klubilisi funktsioone (Jansen-Arukaevu 1995, 29). Tallinnas asutati saksa meestelaulu selts (Revaler Verein für Männergesang) 1849, esimene eesti lauluselts "Revalia" kinnitati Tallinnas ametlikult 1863, ja sellel seltsil oli muidugi ka oma koor. Olulise tähisena peab veel mainima lauluseltsi "Estonia" ja Johann Voldemar Jannseni asutatud meestelauluseltsi "Vanemuine" Tartus, mõlemad loodi aastal 1865. Esimeseks põhikirjaga ja registreeritud maaseltsiks osutus Jüri kihelkonna lauluselts aastast 1866. Baltisaksa kogukonnas levinud seltsiliikumise eeskujul kujunes ka eestlastele oluliseks muusika- ja haridusseltside loomine nii linnas kui maal, nende kaudu rajati vundamenti kultuurilise identiteedi teadlikuks kujundamiseks. 
Rahvuseks kasvamise üheks oluliseks eelduseks on teatud kriitilist piiri ületav valmisolek end kollektiivselt määratleda ja oma saatuse üle otsustada. Ühiskonna liikmel on tavaliselt mitu identiteeti, identiteedi kaudu mõistetakse oma sarnasust ja erinevust teistega võrreldes. Kultuuri kui toimiva süsteemi ehitusmaterjaliks on traditsioon, identiteeti võib käsitleda kui vastava kultuurisüsteemi ühte, fokusseeritud ja väljaeraldatud osa, mis antud rühma esindab ja sümboliseerib ning teistest rühmadest eristab. (Honko 1988.) Tänapäeva kultuuriteoreetikud on traditsiooni mõistet käsitledes tõdenud, et traditsioon ei kandu ajas edasi nagu asi või asjade kogum, vaid see taasleiutatakse sümbolina toimuval ajahetkel (Handler-Linnekin 1984), traditsioon ei ole kultuuriliselt määratud, see on kultuuriline konstruktsioon (Hobsbawm-Ranger 1983).

Rahvust loovaks jõuks on omakorda rahvuslus, mis ühtlasi kaasneb antud ühiskonna kulgemisega agraarühiskonnast industriaalühiskonda. Agraarühiskonda iseloomustab lokaalrühmade kultuuride keerukas struktuur, mida taastoodetakse paikkondlikult, kuid rahvuslus nõuab kultuurilist homogeensust, ühiskultuuri. Industriaalühiskonna kultuuri kujundavad standardiseeritud, kirjaoskusele ja haridusele rajatud kommunikatsioonisüsteemid. Agraarajastu stabiilses endassesulgunud kogukonnas, kes suhtleb teatud kindlas kontekstis, on kultuur tihti nähtamatu - kultuurikandjad ei teadvusta seda endale. Kuid kui mobiilsus ja kontekstiväline suhtlemine saavad ühiskondliku elu olemuseks, siis muutub ühiskultuur identiteedi tuumaks. Rahvuslus kasutab ära varem eksisteerinud ja ajaloolt pärandiks saadud kultuurivarasid, kuid teeb seda väga valikuliselt ja neid radikaalselt muutes. Rahvuslus taaselustab või leiutab oma kohaliku, kirjaoskusega ja spetsialistide poolt vahendatava ühiskultuuri, kus rahvuslus ülistab ennast rahvakultuurist laenatud stiliseeritud laulude ja tantsudega. (Gellner 1994/95.)

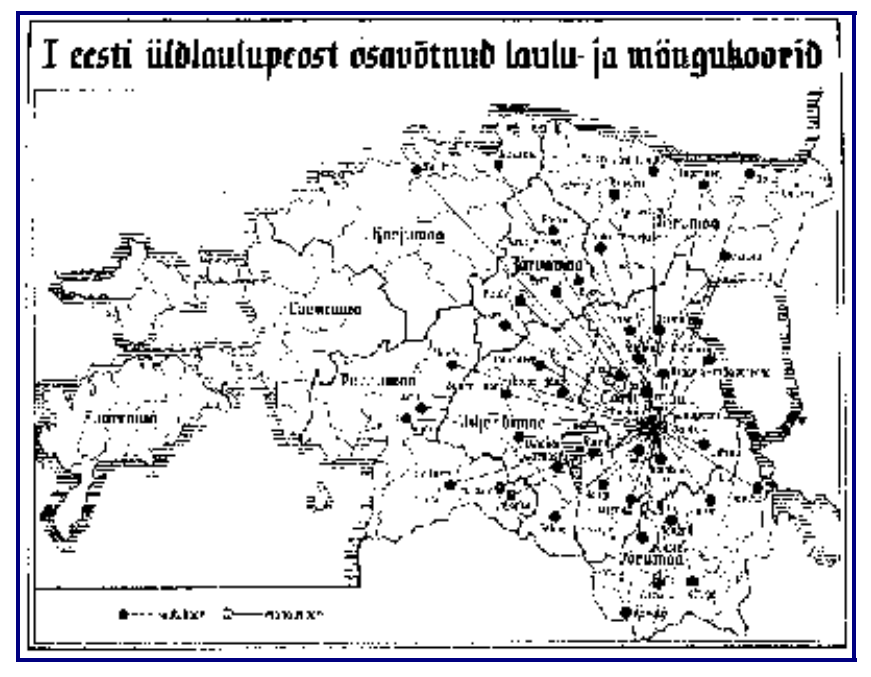

Eesti rahva ajaloos nii kaalukat osa etendanud laulupeo-fenomen kujutab endast kultuurilaenu, millest formeeriti rahvusliku eneseteadvuse kasvatamise tähelepanuväärne tegur, sellest kujundati rahvuslikku identiteeti kandev traditsioon. Saksa kultuuriareaalis harrastatavate suurte laulmispidustuste eeskujul arenes ka baltisaksa Liedertafel lauluseltside avatud ühistegevuse vormiks laulupidude korraldamine, esimene neist toimus 1836. aastal Riias. Oluliseks tõukejõuks koorilaulu energiliseks maarahva hulgas propageerimiseks sai 1857 Tallinnas peetud baltisaksa laulupidu. Oma ajalehes "Perno Postimees" seda sündmust lugejaile tutvustades kiitis Johann Voldemar Jannsen, et Saksamaal on igas külas lauluseltsid (Leichter 1991, 87). Jannsen võttis esimesena kasutusele sõnakombinatsiooni "eestirahvas" senini käibinud "maarahva" või "talurahva" asemel, ning järgneva kümnendi jooksul sai see sõnapaar üldisemalt tuntuks. Mitme koori koosesinemised toimusid laulupüha nime all küll juba 1855 ja 1857 Põlvas, kuid laiema kõlapinnaga esimese kihelkondliku laulupüha kutsus 1863. a. Ansekülas kokku kohalik pastor Martin Körber, sel peol osales 500 lauljat. Põhja-Eestis (ehk täpsemalt tolleaegse administratiivse jaotuse järgi Eestimaa kubermangus) peeti esimene eesti laulupüha kaks aastat hiljem Jõhvis ning juunis 1869 toimus Tartus peale kaheaastast võimudelt loa taotlemist esimene üle-maaline eestlaste laulupidu. Peol astus üles 51 koori ja puhkpilliorkestrit, milles oli ühtekokku 845 esinejat ja publiku hulgaks tuli kahe peopäeva peale kokku 15000 kuulajat! * 
vt.Kaartl Ühtlasi seati nüüd silme ette siht rahvuslikust edenemisest, rahvuslikust ühtsusest ja kultuurilisest enesemääramisest. Siit sai alguse ka müüt, mis meie päevil võttis uut tuult tiibadesse nn. laulva revolutsiooni käigus - müüt sellest, et rahvas võib end vabaks laulda, ja seda ka poliitiliselt. On isegi väidetud, et eestlased laulsid ennast rahvaks. Pärimuslike ja laenatud kultuurielementide põimumise tulemusena loodi rahvusliku kultuurimudeli uus versioon (Dégh 1978, 43).

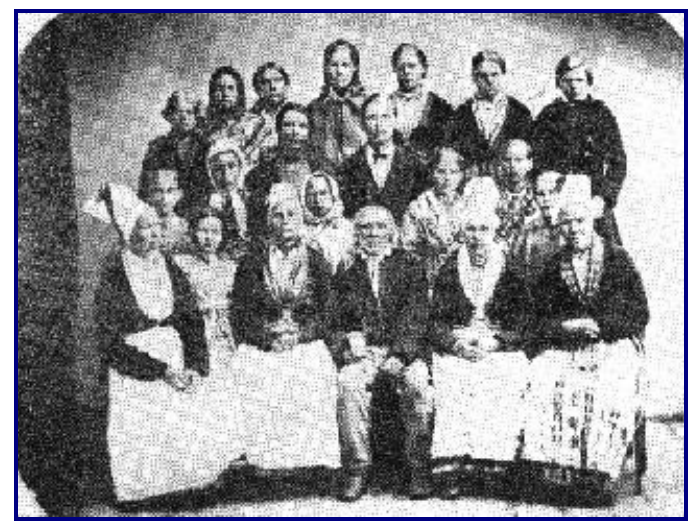

Maa laulukoore ja orkestreid asutasid peamiselt kösterkooliõpetajad, lauljateks ning pillimeesteks olid neis õpetajad, vanemad koolilapsed ning ümbruskonna talurahvas. Niisugune organiseeritud muusikaharrastus on esteetilise ja emotsionaalse eneseväljenduse kõrval ka sotsiaalne tegevus, mille tulemusena laulukooridest arenesid sajandi kolmandal veerandil muusika-, heategevus- ja karskusseltsid. Eelmisel sajandil peetud 6 laulupidu osutusid rahvusluse kõige massilisemaks manifestatsiooniks, vaatamata sellele, et valitses karm tsensuur ning tegevusloa saamiseks tuli kasutada osavaid poliitilisi keerdkäike. Näiteks I üldlaulupeo (mille algatajaks ja peamiseks läbiviijaks oli meestelauluselts "Vanemuine" eesotsas J. V. Jannseniga) toimumisloa kindlustamiseks valiti peokomisjoni aupresidendiks Tartu Maarja kiriku baltisakslasest praost A. H. Willigerode, ning pidu peeti "Liivimaa Talurahva Pärisorjusest Vabastamise 50. aasta Juubeli- ja Tänulaulupeo" nime all. Ka venestuspoliitika ägenemise tingimustes suutsid energilised eesti päritolu haritlased, muusikategelased ja kooliõpetajad selle massikogunemise tava jätkata (I, II, IV ja V pidu peeti Tartus; III, VI ja edasised Tallinnas).* vt. Foto 2 1910. aastal peetud VII üldlaulupidu andis tunnistust eestluse selgroo tugevusest - pidustuste kava sisaldas vaid eesti heliloojate loomingut, kokku tuli juba 527 koori ja puhkpilliorkestrit ligi 10 000 esinejaga (sealhulgas esmakordselt ka lastekoorid), ning peo korraldajad pühendasid oma ettevõtmise "Estonia" seltsi teatrimajale nurgakivi panemisele..* vt. Foto 3

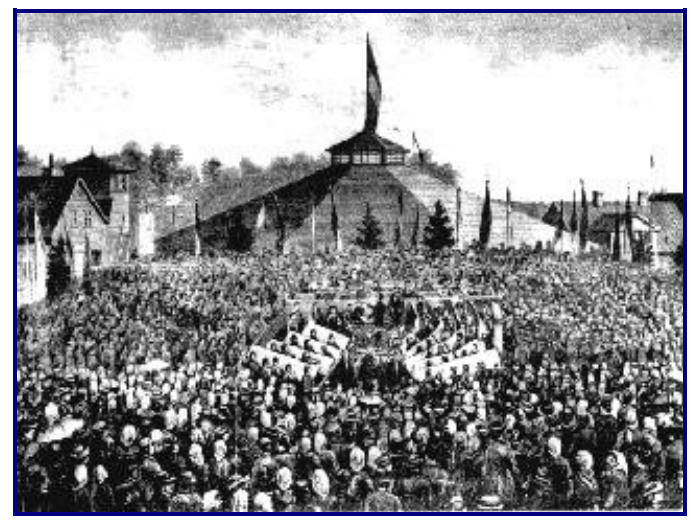

Peale Eesti iseseisvumist ning rahvusvahelist eestlaste rahvusena tunnustamist muutus hulgalise ühislaulmise eesmärgiks rahvusterviku loomine ja eesti muusika propageerimine. Eesti Vabariigi aegsete laulupidude organiseerijaks ja koorilaulu-harrastuse edendajaks oli 1921. aastal loodud Eesti Lauljate Liit, alates VIII üldlaulupeost 1923. a. otsustati suurejoonelisi ühislaulmisi korraldada iga 5 aasta tagant. IX peoks 1928. aastal ehitati spetsiaalne laululava Tallinnas Lasnamäele, nüüdsele Lauluväljakule. Laulupidude tava peegeldab omapäraselt ka eesti ühiskonna emantsipeerumisprotsesse: kui esimestel pidudel astusid üles vaid meeskoorid, siis 1891. a. IV peol osalesid juba ka segakoorid. 1896 (VI) said loa etteasteks ka naiskoorid, kuid ainult võistulaulmisel - päris püünele ei sündinud veel minna. Alles 1933. aastal lülitati naiskoorid omaette esinejatena X üldlaulupeo kavasse. 1938. aastal peetud viimasel ennesõjaaegsel üldlaulupeol osales ühtekokku juba 17 ja pool tuhat esinejat. Võrdväärset populaarsust nautis koorimuusika ka Eesti heliloojate hulgas kooriloomingule eksisteeris ju sotsiaalne tellimus. Laulupeod olid seitsmekümne aastaga juurdunud rahvusliku eneseväljenduse traditsiooniks. $*$ vt. Foto 4 


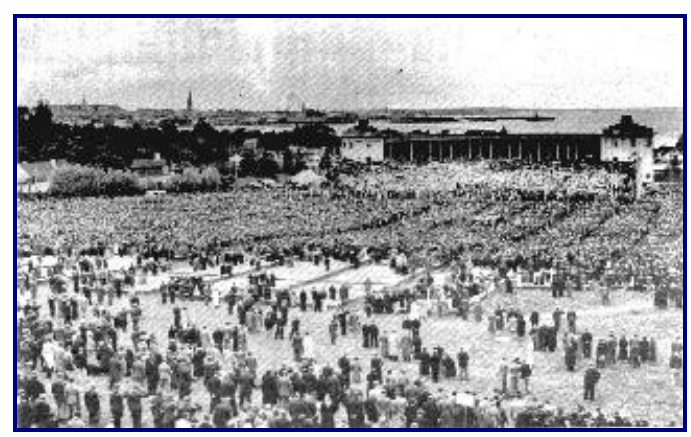

Üheks oluliseks teguriks, mis võimaldas eesti laulupidudel peale Teist maailmasõda edasi kesta, osutus eeldatavasti asjaolu, et järgmine üldlaulupidu toimus aastal 1947, mil stalinlik surverezhiim ei olnud veel kõike avalikult eesti-meelset lämmatanud ning nähtavasti peeti vajalikuks lokaalseid massifenomene adopteerida, neid oma eesmärgi kohaselt mugandades. ${ }^{*}$ vt Foto 6

Olid ju laulupeod (v. a. 1947. ja 1969. aasta omad) ajastatud Eesti NSV ümmargustele aastapäevadele (seda tuli repertuaarivalikus muidugi arvestada) ning suurte massiüritustena andsid neile sära juurde. Siit tulenes küllaltki oluline riiklik toetus meile. Loomulikult püüdis EKP hankida endale plusspunkte nii oma rahva kui Moskva silmis. (Muusikaleht 1994, 10.)

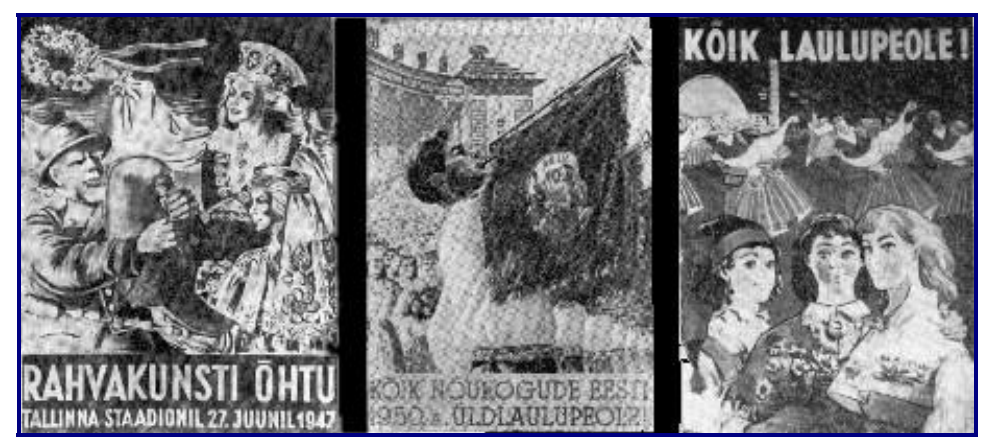

Sel sünge ajastu laulupeol liideti kavasse suurejoonelisuse ja arvukuse tagamiseks omaette üksusena kaevurite koor ja sõdurite koor ning esinejate hulgaks saadi rekordiline 31 907. 1955. aasta (XIV) üldlaulupeol esinesid esmakordselt omaette üksusena vene koorid. 1960 (XV) sai Tallinnas valmis praegune laululava ja esimest korda osalesid poistekoorid. * vt Foto 7 Kuuekümnendateks aastateks oli organiseeritud kooriliikumine ja laulupeod Nõukogude Eesti kultuuripoliitikaga sedavõrd kohanenud, et võidi täiesti teadlikult põlvkondlikule järjepidevusele mõelda - 1956. aastal toimus Tartus esimene üliõpilaste laulupidu "Gaudeamus" (mis omakorda lõi tihedamad sidemed eesti, läti ja leedu akadeemilise noorsoo vahel) ja 1962. aastast hakati korraldama koolinoorte laulupidusid, nii tagati üldine koorilaulu harjumuse edasikandumine, ning ühtlasi tekitati uues põlvkonnas vajadus seesuguse peo järele. Kuigi numeratsioon oli ära keelatud, tähistati 1969. aastal sajandi möödumist esimesest Eesti üldlaulupeost. See poliitilise "sula" järellainetusena oma näo saanud üritus kujunes märkimisväärselt oluliseks laulupeotraditsiooni rahvusliku meelsuse säilitamisel. Pidu oli täiesti ametlikult juubelilaulupidu, selle korraldamisega eirati tavapärast 5-aastast tsüklit ning kava sisaldas palju nn. isamaalisi ja ärkamisaegseid laule, andes kogu üritusele eelkõige eesti rahva ajalugu ja kultuuri pühitseva ilme. Sajandivanustest traditsioonidest elustati võistulaulmise ja -mängimise tava. Peotuli süüdati Tartus - laulupidude sünnilinnas - ja seda kanti kahe nädala jooksul läbi Eestimaa Tallinnasse, mis lõi võimaluse korraldada vastavaid eestlaste eneseteadvust kehutavaid ettevõtmisi kõikjal tule teekonna peatuspaikades. $*_{\text {vt Foto } 8}$

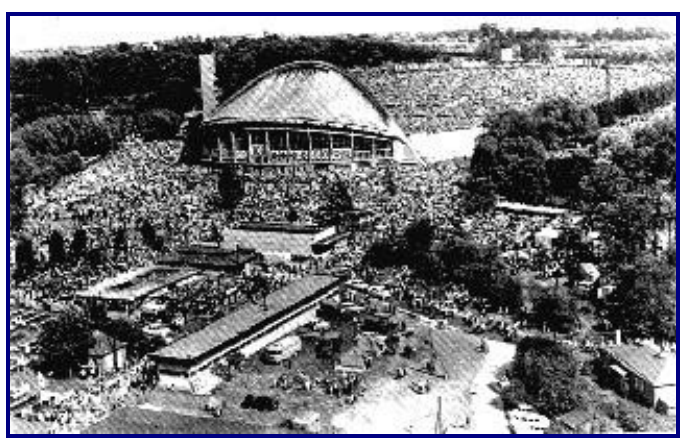


Aastal 1972 ja järjekordsel üldlaulupeo aastal 1975 (XVIII) korraldati Tallinnas rahvusvaheline koorifestival, mis omakorda aitas kaasa nn. pool-professionaalsete kooride tehniliste oskuste edenemisele, soodustades vaieldamatult ka üleüldise harrastusliku koorilaulu taseme tõusu. 1980. ja 1985. aasta (XIX ja XX) laulupidusid iseloomustas ametlikult eriti silmapaistev nõukogudelik ideologiseeritus ja püüd rahvuslikku meelsust vältida, nendel pidudel esinesid eraldi üksusena ka sõjaveteranide ansamblid. Nõukogude-aegsete üldlaulupidude üks staazhikas korraldaja on meenutanud alljärgnevat:

Vaino-aja üheks viimaseks laulupeoks pidime kellegi Keskkomitee ideoloogiaosakonnas töötava venelanna nõudmisel esitama enne laulupidu kogu repertuaari lindistatult. Ühel viimastest laulupidudest tuli avamiseelsel päeval käsk kanda rongkäigus kõigi NLKP Keskkomitee Poliitbüroo liikmete portreesid. Ühe ööga tuli need valmis teha. Alaline nägelemine oli rongkäigus punaloosungite kandmise üle. Tavaliselt kõlasid kurtidele kõrvadele väited, et rahvariiete keskele need ei sobi, et laulupeorongkäik pole mai-või oktoobridemonstratsioon. Oli kindlaks määratud, kes mingit Tallinnas valmistehtud loosungit hakkab kandma. Ühe viimase laulupeo järel tõmmati autasustamiseks ettepandud dirigentide nimekirjast maha ühe dirigendi nimi, kuna tema koor oli loosungi jätnud maha laulupeoliste kogunemispaika Tõnismäel. (Muusikaleht, juuni 1994, 10.) * vt Foto $9,10,11$

Peale 1988. aasta pöördelist suve, mil spontaansed "öised laulupeod" ja poliitilised koosolemised-ühislaulumised Lauluväljakul näitasid selle kultuurifenomeni tõelist organiseerivat jõudu manifesteerimaks rahvuslikku eneseteadvust ja ühtekuuluvust, toimus 1990. aasta (XXI) üldlaulupidu täiesti muutunud oludes. Märkimisväärseimaks jooneks sel peol sai pagulaseestlaste "kojujõudmine" - olid ju nemadki eksiilis oma rahvuslust turgutanud laulupidude traditsiooni jätkates. Selle peo eel taastati ka laulupeo tule pidulik nädalane teekond Tartust Tallinnasse. 1994. aasta suveks, mil toimus XXII üldlaulupidu, oli Eesti juba kolm aastat iseseisev olnud ja massikogunemistest kaunikesti tüdinenud, ühislaulmine ei olnud enam vastupanukultuuri osa. Kuid vaatamata sellele ja õhus (ajakirjanduses) hõljuvale skepsisele, et eesti rahva laulupidude aeg on ümber, osutus osavõtt juubelilaulupeost, tähistamaks 125 aasta vanust traditsiooni,

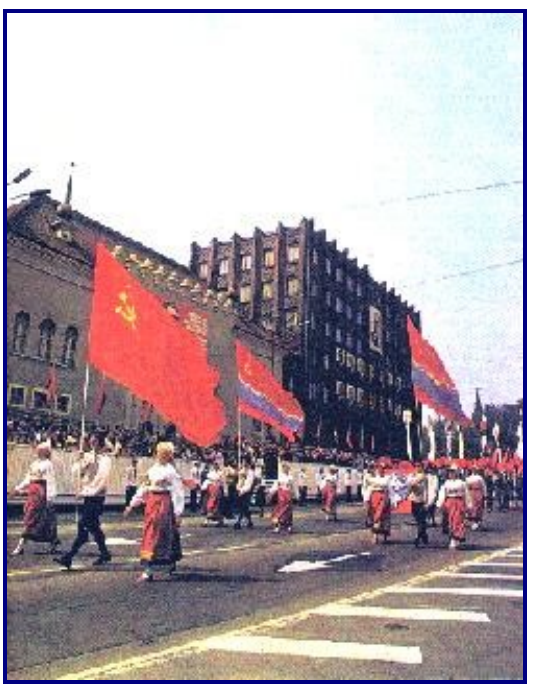
hämmastavalt rahvarohkeks. Pidu toimus ju isegi kahes linnas - Tartus laulis 16000 lauljat publikule, mille arv ulatus 70 tuhandeni, ja nädal hiljem (peale laulupeo tule pidulikku teekonda läbi Eesti) astus Tallinnas üles ühtekokku 25000 esinejat 100000 pealtvaatajale. * vt. Foto 12 Kuna koorilaul on Eestis kujunenud massiharrastuseks, siis on päris loomulik, et keskmise eestlase jaoks seostuvad sõnad 'rahvas' ja 'laulmine' mõistega 'laulupidu'. 


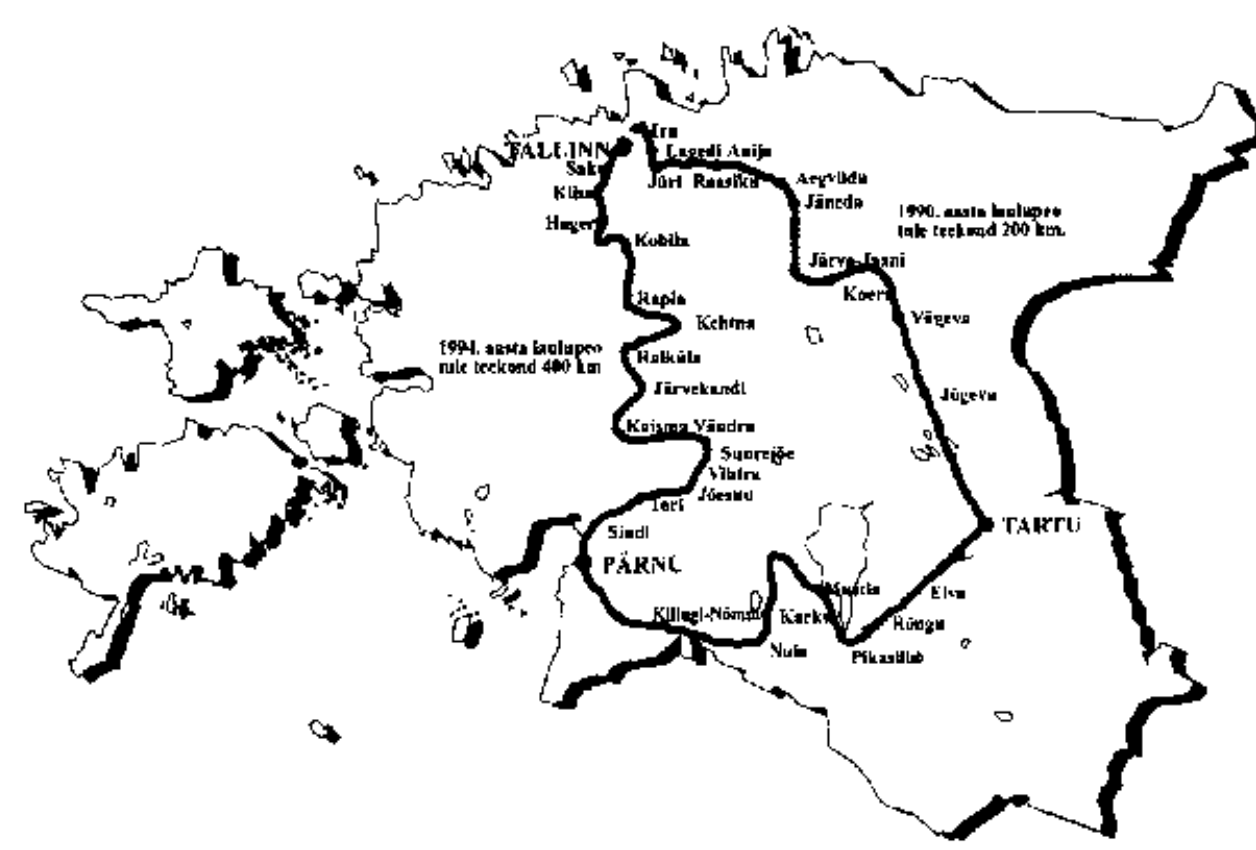

Valitsevale poliitilisele võimule vaatamata on laulupeod kontseptuaalselt tähendanud oma kultuurilise identiteedi demonstratsiooni. $\mathrm{Ka}$ nõukogude-aegses ideologiseeritud ja administreeritud kultuuritegevuse tingimustes kandsid laulupeod ja kooriliikumine kas eksponeeritud või varjatud kultuurilist märgisüsteemi (Geertz 1973), mida me tänases perspektiivis nimetame

eestluse säilitamiseks. Ajastule iseloomulikult ambivalentsetena (kõikudes võimutruuduse ja rahvusluse eksponeerimise vahel) osutusid laulupeod pea ainsateks nii mastaapseteks vabatahtlikkuse alusel toimuvateks massikogunemisteks. Rahvusliku identiteedi säilitamise kohta tehtud uuringu tulemused näitavad, et kõige tugevam faktor eestluse säilitamisel oli osavõtt laulupidudest (Rakfeldt 1996, 1574).

Kuigi nõukogude ametlik kultuuriideoloogia oli eesti laulupidude institutsiooni integreerinud valitseva võimu teenistusse ning ametlikus programmis välditi hoolikalt igasuguseid natsionalistlike tunnete väljendusi, jätkasid need rahvakogunemised tegelikult oma võimutruu fassaadi varjus ja selle kiuste rahvusliku ühtsuse ja kultuuriidentiteedi säilitamist. Lauljatel ja publikul kujunesid teatud sümboolsed rituaalid rahvuslike väärtuste eksponeerimiseks ja põlistamiseks. Niisuguseks ilminguks oli muuhulgas rahvariiete kandmine (mis sageli avalikult demonstreerisid kodukoha tunnetust), või teatud tähendusrikaste ja kõneka ajalooga laulude ühislaulmine peale ametliku kava lõppu. Laulupeo rongkäik sai omamoodi massidemonstratsiooniks, kuhu tuldi ju vabatahtlikult (vastandina sunniviisil marssimisele punasel oktoobri- või maiparaadil), kohustusliku võimutruu regalia kõrval kanti oma koori ja kodukanti iseloomustavaid lippe, märke. Ja nendel rongkäikudel osales aktiivselt ka arvukas publik - vastastikku hõiguti tunnustavaid hüüdlauseid, lauldi rahvuslikke laule. 


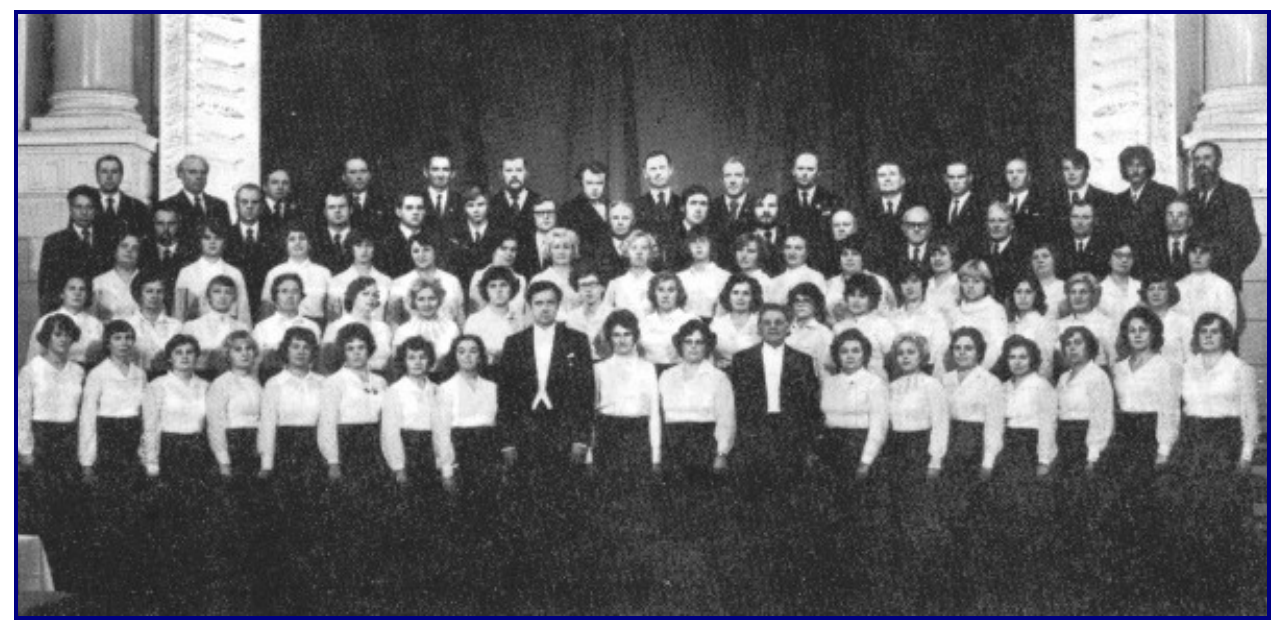

Paljudel kooridel üle Eesti oli otsene side sõjaeelse seltsitegevusega (oma parimatel päevadel võis kooris olla isegi 130 lauljat, seega vähemat sorti seltsi jagu), mitmed koorid lugesid ametlikult oma tegevusaastaid eelmisest sajandist alates, oldi teadlik oma ajaloost, kodukandi kultuuriloost, sageli peeti oma koori kroonikaraamatut. Koorielu korralduses kasutasid paljud koorid traditsioonilisi atribuute ja tseremooniaid: koori märki, lippu, mütsi, uue liikme piduliku vastuvõtmise riitust, eraeluliste ja kalendritähtpäevade (eelkõige rahvakalendri, mitte riiklike) tähtpäevade tähistamist. Tugevamate traditsioonidega koorid kultiveerisid ilmselgelt kodukoha tunnetust - kuna koori ainsaks või üheks oluliseks esinemisriietuseks olid rahvariided, siis sai selle kaudu manifesteerida oma paikkondlikku päritolu, sageli valmistas koori naispere oma näputöö-õhtutel vähemalt mõnedki rahvariiete detailid. $*^{*}$ vt. Foto 13 ja $*$ vt. Foto 14 . Kooris lauldi aastakümneid, selle kaudu hoiti ka põlvkondade sidet ja jätkati traditsioone. Ühistegevuse, koosviibimiste, bussisõitude ja reisimiste ajal kõlas laulurahva suust loomulikult laul, ning see repertuaar oli täiesti spontaanne, lorilauludest keelatud isamaaliste lauludeni. Oma laulupeo elamusi kirjeldab 21 aastat "Koidu" kooris laulnu:

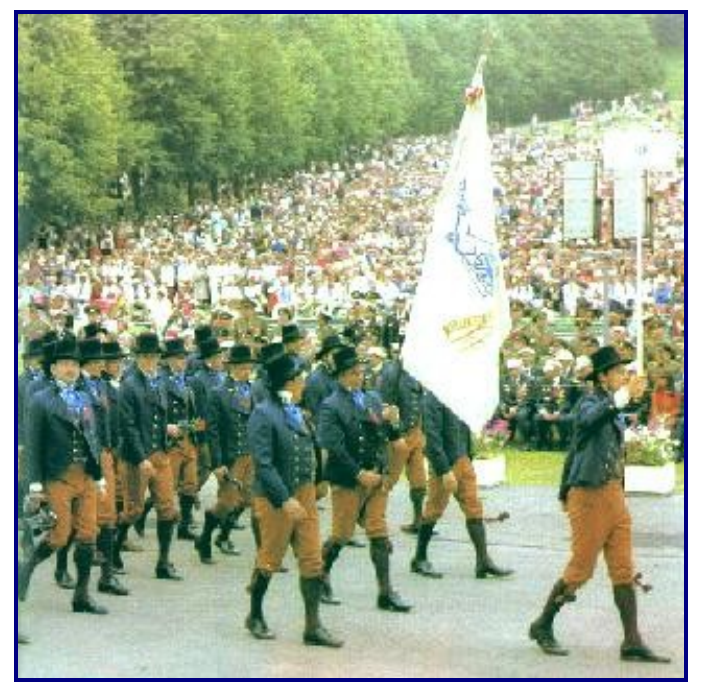

Küllap on paljudele vanematele lauljatele meelde jäänud 1960. aasta üldlaulupidu Tallinnas. 20. juunil, kui meie rajooni kolonn oli just liikuma hakanud, kärgatas Kaarli kiriku taga kõu ja hakkas sadama. Sammusime vapralt lauldes lauluväljaku poole, tihe rahvamüür tee ääres laulis meiega kaasa. Kui Kadriorgu jõudsime, polnud mere ja taeva vahel enam piiri. Tohutu piksepilv oli mere kohal ja sähvis välke. Kui jõudsime laululava taha, hakkas sadama jämedat vihma. Kõik ei mahtunud lava katuse alla. Ja siis tuli tõeline paduvihm. Selle all jooksid väljakule tulekandjad. Peagi järgnes korraldus, et kontsert lükatakse homsele ja kõik võivad koju minna. "Tahame laulda," skandeerisime lavalt ja kohe võtsid meeshääled üles "Kungla rahva". Järgnesid "Mutionu pidu", "Metsa läksid sa" ja "Kui see laul meil. . ." Dirigenti polnud, kuid suur koor laulis rütmis ja kõikumatult. Järgesid "Kaunimad laulud", "Koit" ja "Meeste laul" - ikka veel juhita. Siis aga vehkis keegi meeste keskelt mahtra malakaga ja koor hakkas skandeerima "Harald Uibo! Gustav Ernesaks!" Ernesaks lõpuks tuligi ning algas kooriliikide võistulaulmine. Vihma sadas ja äike raksus, kuid seda nagu ei märgatudki. All väljakul istusid tõelised laulusõbrad ja vibutasid aplausiks vihmavarje. Järgmisel päeval polnud taevas ainsatki pilve. Ja ime küll, noorikute särgid, 
põlled ja tanud olid valged ja triigitud, ainult seelikud olid veel märjad. "Koidu" meeste särgid olid aga vihmast sinisekirjalised. Toimus tõeline kontsert, kusjuures laulsime ära ka eelmise päeva laulud. (Viljandi. . . 1994, 55.)

Koorikontserdid pakkusid ametlikku võimalust rahvuslike rahvakogunemiste korraldamiseks: näiteks Teaduste Akadeemia Meeskoori esimene kontsert 1958. a. tähistas 100 aasta möödumist "Kalevipoja" ilmumisest. Ja järgnevast kümnendist alates kujunesid eelkõige Veljo Tormise meie algupärast etnilist teksti ja muusikat austavad, regivärsilisele laulupärandile tuginevad koorikompositsioonid avameelseks ning ideoloogiliselt raskemini kontrollitavaks rahvuslike taotluste kandjaks, jõudes uudse koorirepertuaarina lauljate laiade hulkade sekka ja saades teadliku etnilise identiteedi väljendajaks. Rahvatraditsioonide viljelemise kaudu oli võimalik eksponeerida ja nautida "meie" tunnet, mis polnud tsenseeritav.

Laulukooride (ja laulupidude) repertuaari kuulusid ideoloogilisest survest hoolimata paljud eelmise sajandi ärkamisaegsed ja hilisemadki, lauljate jaoks aegade sidet kinnitavad ja isamaalisi tundeid kosutavad laulud. Eriti tähendusrikkaks osutus laul "Mu isamaa on minu arm", luuletuse autoriks Lydia Koidula ning I üldlaulupeo kavas olnud loo viisi autoriks Aleksander Kunileid. Nendele ärkamisaegsetele sõnadele lõi Gustav Ernesaks Teise maailmasõja ajal Venemaa tagalas uue viisi. Ernesaks oli laulurahvale sõjaeelsest ajast tuttav kui Tallinna Naislaulu Seltsi koorijuht, aga Nõukogude võimuaparaadile vastuvõetav kui Venemaa tagalas tegutsenud "kunstnik-võitleja". Laulupidude organisaator meenutab:

Gustav Ernesaksal oli omakorda väga suur osakaal pingete maandamisel ja normaalse õhkkonna loomisel. Tal oli, eriti algupoolel, väga suur autoriteet ka võimulolijate silmis. Oleks täielikult mahtunud tollase protokolli raamidesse, kui Valge Maja andnuks oma korraldused temale üle läbi mõne kultuuriministeeriumi ametniku. Nii see tihtipeale Vaino ajal ka toimus. Aga Ernesaks rääkis ise korduvalt, et $N$. Karotamm ja J. Käbin vestlesid temaga ikka isiklikult ja sõbralikult. Viimase kanaaegse parteibossiga olid tal head suhted: Käbin kiitis Ernesaksa ja Ernesaks Käbinit. Oma suure autoriteediga ka võimulolijate juures osutas Ernesaks eesti laulupeoliikumisele hindamatuid teeneid. Ta oli ise paljude ideede generaator ja toetas mõtteid, mis sündisid tema lähikonnas. Sel kombel said näiteks teoks peale Koorijuhtide Vabariikliku Segakoori moodustamise (1958. a. K.K.) ka vabariiklike koolinoorte laulupidude traditsiooni algatamine. Tema kui repertuaaritoimkonna ja hiljem Koorisektsiooni Nõukogu esimehe arvamust arvestati võimuorganeis väga. (Muusikaleht, juuni 1994, 11.)

"Mu isamaa on minu arm" oli 1947. aasta laulupeo kavas, kuid 1950. a. kommunistliku partei VIII pleenumi tulemusena lülitati laul kavast välja, kuigi koorid olid laulu ette valmistanud. Laulupeo ajal jäi peale laulurahva tahe ning hiigelkoor hakkas laulma ilma dirigendita, Ernesaks siiski lubati dirigendipulti, et laul tema juhtimisel lõpuni laulda. 55. ja 60. aasta üldlaulupidudel seda laulu ametlikus programmis ei olnud (korraldajate sõnutsi olla see pandud nö. lisapalade nimekirja - vt. Muusikaleht 1994, 11). Alates 1965. a. on "Mu isamaa on minu arm" küll olnud kõigi (ka koolinoorte) laulupidude kavas, kuid nii esinejate kui publiku jaoks omandas eriti olulise tähenduse selle laulu spontaanne ühislaulmine peale ametliku kava lõppu. See laul kujunes omamoodi hümniks, mis nagu sümboliseeris kõiki neid laule, mida laulda ei tohtinud. Laulupidude lõpetamine tekitas korraldajatele alati probleeme, sest koorid pole kunagi pärast peo ametlikku lõpetamist 
tahtnud lavalt lahkuda, ühislaulmise tahet pole suudetud lämmatada ei puhkpillimuusika ega üldjuhtide äraviimisega laululava eest. Ja ka pealtvaatajad igatsevad kogeda seda ülendavat tunnet, mis tekib tuhandete teistega üheskoos samu sõnu ja sama viisi lauldes. Seesugune massiline kunstiline eneseväljendus tugevdas rahvuslikku teadvust, toetas rahvuslike hoiakute ja väärtusorientatsioonide säilimist. Järgneva mälestuskillu on kirja pannud 45 aastat segakooris "Koit" laulnud naine:

Laulupeod ja nende juurde kuuluvad rongkäigud on andnud elamusi, mida kuskilt mujalt ei saa. Ja muidugi laulmine suures laulupeokooris! Ma ei unusta kunagi Gustav Ernesaksa nägu, kui ta tuli keelatud laulu poole pealt juhatama. See oli 1960. või 1965. aasta laulupeol. Tema "Mu isamaa on minu arm" pidi süvendama natsionalismi. Ent rahvas hakkas seda ise laulma, hoides kätest kinni. Koorijuhid vajusid juhtimispuldist eemale, ju oli neid enne töödeldud. Lauljad said siiski oma tahtmise. Laulupeod aitasid eesti rahvast, ükskõik mis sildi partei ja valitsus üles riputasid. (Viljandi. . . 1994, 52.) * vt. Foto $15,16,17$

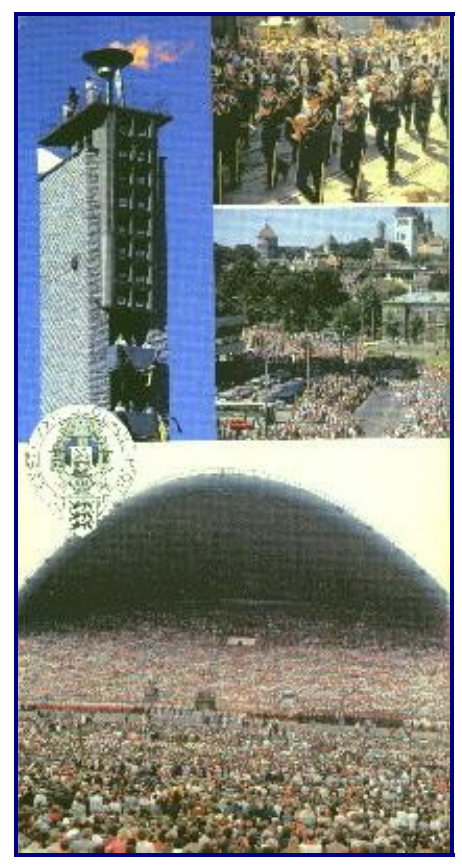

Laulupidu on rahvapidu, mis on ühtlasi rituaal ja vaatemäng. Laulupidu loob situatsiooni, kus demonstreerida oma kultuurilist identiteeti ja rahvuslikku ühtsust. Selle ürituse mehhanismiks on sotsiaalne mobilisatsioon, peole tullakse perekonniti ja sõpradega, kunstilisest elamusest on tähtsam suhtlemine lähedalt ja kaugelt tulnutega, vajadus kogeda taassulandumist ühiskonda laiemalt, ühtsustunnet kogu rahvaga, tema ajaloo ja kultuuripärandiga. Rahvapeo käigus toimuvad organiseeritud ja publikule orienteeritud kunstilised etteasted demonstreerivad antud kogukonna kultuuriharrastust, kandes kolme peamist funktsiooni: sotsiaalset funktsiooni kogukonda organiseerida; psühholoogilist funktsiooni väljendada isiklikke ja kollektiivseid emotsioone; ja kolmandaks - funktsiooni eksponeerida, tugevdada ning luua antud kultuuri (Turner-McArthur 1990, 86).

Laulupidu kui rahvapidu loob kommunikatiivse situatsiooni, mis kõiki osavõtjaid aktiivselt kaasab, võimaldades osalemise (participation) ja esitamise (performance) kombinatsiooni ühiskondlikus kontekstis. Rahvapeol osalemise üheks motivatsiooniks on sotsiaalne interaktsioon, mille kaudu selgitatakse ja korraldatakse mitmesuguseid suhteid. Rahvapidu sisustavad tegevused peegeldavad antud kogukonna huvisid, luues seega võimaluse konkreetse etnilisuse väljendamiseks, millega kaasneb eneseteadvuse tugevdamine, poliitiline aktsioon ja ühiskonna elujõu kinnitamine (revitalization). Rahvapidu toetab kogukonna taasloomist (regeneration) ja korraldab kogukonna elu, see tugevdab rühma identiteeti ja tema võimet enda huvides tegutseda, aidates kaasa sotsiaalsete probleemide artikuleerimisele. Rahvapeo sõnumid puudutavad rühma ühist kogemust ja selle kogemuse mitmetasandilist interpretatsiooni. Rahvapidu koondab kogukonna kokku, pakkudes pilti nii ühiskonnast kui indiviidi rollist selles. (Stoeltje 1992.) Laulupeo toimumise ajal kogetakse taassulandumist ühiskonda laiemalt, samastumist oma rahva, tema ajaloo ja kultuuripärandiga. See kultuuriline etendus on ühtlasi kollektiivne "tekst" antud ühiskonnast, lugu meist endist, nagu meie seda endale jutustame (Geertz 1973). 


\section{Kasutatud kirjandus}

Arvo Ratassepp meie meeltes. Eesti Meestelaulu Seltsi väljaanne. Tallinn, 1994.

Dégh, Linda 1978. The Study of Ethnicity in Modern European Ethnology. Folklore, Nationalism and Politics. Ed. Felix Oinas. Columbus.

Geertz, Clifford 1973. The Interpretation of Cultures. New York.

Gellner, Ernest 1994/95. Rahvused ja rahvuslus. Akadeemia nr. 10-12/1-3.

Handler, Richard; Linnekin, Jocelyn 1984. Tradition, Genuine or Spurious. Journal of American Folklore nr. 97, 273-290.

Hobsbawm, Eric; Ranger, Terence (eds.) 1983. The Invention of Tradition. Cambridge.

Honko, Lauri (toim.) 1988. Tradition and Cultural Identity. NIF Publications no. 20. Turku.

Jansen, Ea; Arukaevu, Jaanus (toim.) 1995. Seltsid ja ühiskonna muutumine: Talupoja ühiskonnast rahvusriigini. Tartu-Tallinn.

Lauluga läbi aegade (laulupidude ajaloost). Koost. A.Tamarkin. Tallinn, 1965.

Laulupeo teatmikud. Tallinn, 1985, 1990, 1994.

Leichter, Karl. Seitse sajandit eestlaste lauluteel: Kultuuriloolisi andmeid aastaist 1172-1871.

Tallinn, 1991.

Muusikaleht 1994. Nõukogudeaegsete üldlaulupidude köögipoolelt. Laulupeo Muusikaleht, erinumber. Juuni 1994.

Põldmäe, Rudolf. Vennastekoguduse muusikalisest tegevusest meie maal. Teater. Muusika. Kino nr. 2, 1988.

Rakfeldt, Jaak; Rakfeldt-Leetmaa, Helle 1996. Rahvusliku identiteedi säilitamine okupeeritud Eestis. Akadeemia nr. 8, 1571-1590.

Ratassepp, Arvo. Eesti laulupeod. Tallinn, 1985.

Stoeltje, Beverly J. 1992. Festival. Folklore, Cultural Performances, and Popular Entertainments. Ed. Richard Bauman. New York.

Turner, Rory; McArthur, Philip H. 1990. Cultural Performances: Public Display Events and Festival. The Emergence of Folklore in Everyday Life. Bloomington, Indiana.

Viljandi. . . 1994. Viljandi Kultuuriselts "Koit" 125. Viljandi Kultuurisletsi "Koit" väljaanne. Viljandi. 